\title{
Effects of Cereal Type, Enzyme and Sodium \\ Butyrate Addition on Growth Performance, Carcass Traits and Intestinal Morphology of Broilers
}

\section{-Author(s)}

Shahir $\mathrm{MH}^{1}$

Moradi $\mathrm{S}^{1}$

Afsarian $\mathrm{O}^{1}$

Esmaeilipour $\mathrm{O}^{2}$

Department of Animal Science, Faculty of Agriculture, University of Zanjan, Iran

2 Department of Animal Science, Faculty of Agriculture, University of Jiroft, Iran

\section{ABSTRACT}

A $2 \times 2 \times 2$ factorial arrangement was conducted to evaluate the effects of cereal type (corn vs. wheat), enzyme supplementation (0 or $0.4 \mathrm{~g} / \mathrm{kg}$ diet), and sodium butyrate addition ( 0 or $2 \mathrm{~g} / \mathrm{kg}$ diet) on growth performance, carcass traits and intestinal morphology of male broilers from 10 to $42 \mathrm{~d}$. A total of 600 male Arbor Acres chickens were assigned to eight dietary treatments in a completely randomized design, providing five replicate pens per treatment. Diets were formulated to meet or exceed NRC nutrient recommendations. When compared with birds fed corn-based diets, chickens fed wheat-based diets had inferior weight gain (1978 vs. $1807 \mathrm{~g}, \mathrm{p}<0.01$ ) and feed per gain ratio (1.81 vs. 1.93; $\mathrm{p}<0.01)$. Both weight gain (1870 vs. $1915 \mathrm{~g} ; \mathrm{p}<0.01)$ and feed intake (3511 vs. $3556 \mathrm{~g} ; \mathrm{p}<0.01$ ) were increased by enzyme addition to experimental diets. Feed intake significantly $(p<0.01)$ increased by sodium butyrate addition to experimental diets; however, no significant differences were observed in weight gain or feed per gain ratio when sodium butyrate added to experimental diets. The birds fed wheatbased diet had higher relative weights of the proventriculus $(p<0.01)$, gizzard $(p<0.05)$, liver $(p<0.05)$, duodenum $(p<0.05)$, and ceca ( $p$ $<0.01)$ when compared with those fed corn-based diet. Enzyme and sodium butyrate addition had no significant effects $(p>0.05)$ on the relative weights of the proventriculus, gizzard, pancreas, liver and heart. Cereal type had a significant $(p<0.05)$ effect on intestinal morphology, including villus height and crypt depth. Jejunal villus height $(p<0.05)$ and crypt depth $(p<0.01)$ were improved by sodium butyrate addition. In conclusion, the results of this experiment showed that enzyme and sodium butyrate addition, especially to the wheat based diet, improve growth performance.

\section{INTRODUCTION}

Corn is commonly used as the main source of energy in poultry diets; however, it is sometimes difficult to maintain least-cost diet formulations using corn in the Iranian poultry industry production due to an unstable grain market. When the price difference between wheat and corn is too high, poultry producers frequently substitute corn by wheat. Compared with corn, wheat energy content is lower, but the levels of many other nutrients, including protein and many amino acids, such as lysine, arginine, phenylalanine, tryptophan, are higher in wheat (NRC, 1994). Wheat contains relatively high levels of non-starch polysaccharides (NSP) in the cell wall layers that cannot be digested in the small intestine of monogastric animals due to the lack of endogenous enzymes. The accumulation of NSP (e. g. arabinoxylans) in alimentary tract results in water retention and increases the viscosity of digestive contents. It is well documented that high digesta viscosity has 
a negative effect on nutrient digestion and absorption (Choct \& Annison, 1992a) and modifies gut microflora (Choct et al., 1996). It has been demonstrated that high dietary soluble NSP is associated with $C$. perfringens proliferation (Annett et al., 2002) and that it may also affect the prevalence of Salmonella spp. and other pathogens in the intestines of chickens (Branton et al., 1997).

Considering the reasons mentioned above, enzymes are required to reduce wheat NSP levels. Enzyme (ENZ) supplementation has a direct positive effect on animal performance by improving nutrient digestion and absorption, thereby reducing substrate availability for the growth of microbial pathogens in the ileum (Bedford \& Apajalahti, 2001). Generally, these enzymes hypothesized to work in two steps, described as an ileal phase and a cecal phase (Bedford, 2000). During the ileal phase, enzymes remove fermentable substrates. During the cecal phase, degradation products of sugars, such as xylose and xylo-oligomers, are fermented by cecal bacteria, stimulating the production of volatile fatty acids (VFA) and the growth of specific beneficial bacteria. In the process of depolymerization various polysaccharides in the diet, enzymes may produce manno- , galacto- , gluco-, or xylo-oligomers, which are similar to prebiotics and which may facilitate the proliferation of health-promoting bacteria such as Lactobacillus and Bifidobacterium (Monsan \& Paul, 1995).

Studies with broilers have indicated a positive response in growth performance from the addition of various organic acids (OA) to diets (Skinner et al., 1991). OA have been considered as a suitable alternative for antibiotics in pig and poultry diets (Dierick et al., 2002). The mechanism by which OA improve performance in broiler chicks has not been clearly determined. It is proposed that OA improve bird performance because of their antimicrobial activity, which enhances protein and energy digestibility by reducing microbial competition with the host for nutrients and endogenous nitrogen losses, and by lowering the incidence of subclinical infections and the secretion of immune mediators (Dibner \& Buttin, 2002). Adding OA to animal diets can lower the gastric pH (Ravindran et al., 1993; Garrido et al., 2004). Low gastric $\mathrm{pH}$ accelerates the conversion of pepsinogen to pepsin, which enhances the absorption rate of nutrients such as proteins, amino acids and minerals (Youn et al., 2005). Because of the biochemical characteristics of $\mathrm{OA}$, they penetrate the cell membranes of pathogenic bacteria and lower the $\mathrm{pH}$ inside the cells. This low
pH kills pathogenic bacteria through the depletion of metabolic energy, the decrease of cell membrane metabolism, the outflow of cell fluids, and the blockage of the use of nutrients (Kirchgessner \& Roth, 1982).

Besides its bactericidal activity, butyrate seems to play a role in development of the intestinal epithelium. Butyrate, which is a by-product of microbial fermentation of substances such as resistant starch, is considered to be important for the normal development of epithelial cells (Pryde et al., 2002). Therefore, butyric acid seems to be both bactericidal and a stimulant of intestinal epithelium. Thus, the objective of this study was to determine the effects of the addition of exogenous enzyme (ENZ) supplementation and sodium butyrate (SB) to corn and wheat-based diets on the performance, carcass traits and gastrointestinal morphology of broilers.

\section{MATERIAL AND METHODS}

\section{Housing and Management}

A total of 600 male Arbor Acres broiler chickens, vaccinated for infectious bronchitis, were purchased from a commercial hatchery. All birds were fed the same diet until $10 \mathrm{~d}$ of age. Forty pens were randomly assigned to eight treatment groups, with 15 birds per pen. Each pen provided $1.5 \times 1.5 \mathrm{~m}$ of floor space, with new wood shavings for bedding. Feed and water were provided ad libitum. Water was provided in nipple-type drinkers and feed was provided in trough feeders. At $1 \mathrm{~d}$ of age, the temperature was set at $33^{\circ} \mathrm{C}$ and then the temperature was reduced in $3^{\circ} \mathrm{C} / \mathrm{wk}$. Lights were on continuously for the first $3 \mathrm{~d}$ post-hatching, after which a 23L:1D lighting schedule was maintained for the duration of the experiment.

\section{Experimental Design and Diets}

A completely randomized design in a $2 \times 2 \times 2$ factorial arrangement was used to study the effects of cereal type (corn- or wheat-based), ENZ (0 or $0.4 \mathrm{~g} /$ $\mathrm{kg}$ ), and SB addition (0 or $2 \mathrm{~g} / \mathrm{kg}$ ). SB was purchased from Ding Su Co., China. The enzyme [Grindazyme (GP15000)] was supplied by Danisco Animal Nutrition (Marlborough, UK). Grindazyme supplies $18000 \mathrm{U}$ of beta-Endoglucanase activity (EC 3.2.1.4) and 43000 $U$ of xylanase. Diets were free from antibiotics and coccidiostats and were formulated to contain 3,100 $\mathrm{kcal}$ of ME/kg and $20.5 \%$ CP in the starter phase and $3,200 \mathrm{kcal}$ of ME/kg and $19.5 \% \mathrm{CP}$ in the grower phase (Table 1). All diets were used in the mash form. 
Table 1 - Composition and calculated analysis of experimental diets

\begin{tabular}{|c|c|c|c|c|}
\hline \multirow{2}{*}{ Item } & \multicolumn{2}{|c|}{ Corn-based diets } & \multicolumn{2}{|c|}{ Wheat-based diets } \\
\hline & Starter & Grower & Starter & Grower \\
\hline \multicolumn{5}{|l|}{ Ingredient (\% of diet) } \\
\hline Corn & 58.4 & 61.3 & 24.3 & 18.4 \\
\hline Wheat & 0 & 0 & 40 & 50 \\
\hline Soybean meal & 30.5 & 26.35 & 24.6 & 18.5 \\
\hline Vegetable oil & 4 & 4.65 & 4 & 5 \\
\hline Fish meal & 4 & 4.85 & 4 & 5.5 \\
\hline Calcium carbonate & 1 & 1 & 1 & 1 \\
\hline Dicalcium phosphate & 1.2 & 1 & 1.2 & 1 \\
\hline Salt & 0.25 & 0.25 & 0.25 & 0.25 \\
\hline Mineral and vitamin premix ${ }^{1}$ & 0.50 & 0.50 & 0.50 & 0.50 \\
\hline DL-Methionine & 0.12 & 0.10 & 0.12 & 0.10 \\
\hline L-Lysine $\mathrm{HCl}$ & 0.03 & 0 & 0.03 & 0 \\
\hline \multicolumn{5}{|l|}{ Calculated analysis } \\
\hline $\mathrm{CP}(\%)$ & 20.5 & 19.5 & 20.5 & 19.5 \\
\hline ME (kcal/kg) & 3100 & 3200 & 3100 & 3200 \\
\hline Lysine (\%) & 1.14 & 1 & 1.11 & 1 \\
\hline Methionine (\%) & 0.46 & 0.41 & 0.45 & 0.41 \\
\hline Methionine + cystine (\%) & 0.82 & 0.75 & 0.83 & 0.76 \\
\hline Calcium (\%) & 0.95 & 0.92 & 0.95 & 0.96 \\
\hline Available phosphorus (\%) & 0.5 & 0.49 & 0.5 & 0.5 \\
\hline
\end{tabular}

'Mineral and vitamin premix provided the following: $\mathrm{Mn}, 89 \mathrm{mg}$; Zn, $88 \mathrm{mg} ; \mathrm{Fe}, 34$ mg; Cu, 63 mg; Se, 0.3 mg; l, 1.8 mg;

vitamin A, 6,238 IU; vitamin D3, 2,275 IU; vitamin E, $20 \mathrm{IU}$; vitamin B12, $0.013 \mathrm{mg}$; vitamin K, $2.9 \mathrm{mg}$; niacin, $75 \mathrm{mg}$;

folic acid, $0.86 \mathrm{mg}$; biotin, $0.1 \mathrm{mg}$; riboflavin, $5.5 \mathrm{mg}$ per kilogram of the starter diet; and $\mathrm{Mn}, 71 \mathrm{mg} ; \mathrm{Zn}, 71 \mathrm{mg} ; \mathrm{Fe}, 27 \mathrm{mg}$;

Cu, 50 mg; Se, 0.24 mg; I, 1.4 mg; vitamin A, 4,990 IU; vitamin D3, 1,820 IU; vitamin E, $16 \mathrm{IU}$; vitamin B12, $0.011 \mathrm{mg}$;

vitamin K, 2.3 mg; niacin, 60 mg; folic acid, 0.69 mg; biotin, 0.08 mg; riboflavin, 4.4 mg per kilogram of the grower diet.

\section{Experimental Procedures, Sample Collec- tion, and Chemical Analysis}

The experiment lasted $42 \mathrm{~d}$ and consisted of two phases (10 to $21 \mathrm{~d}$, starter; 22 to $42 \mathrm{~d}$, growerfinisher). Feed intake (FI) and weight gain (WG) were measured on a pen basis in weekly intervals, whereas mortality was recorded daily. Fee intake, WG and feed per gain ratio were calculated for each period ( $d 10$ to 21, d 22 to 42, and d 0 to 42). On d 42, two birds per replicate (10 per treatment) were randomly selected and sacrificed by sodium pentobarbital injection. The gizzard, liver, pancreas and total intestinal were excised, and weighed separately for each bird. Then, the small intestine from each bird was opened, and used for intestinal morphological evaluation. All procedures were approved by the University Institutional Animal Care and Use Committee.

\section{Histological Methods}

Histological examinations were carried out according to the method of lji et al. (2001). Before fixation in Bouin's solution and paraffin embedding, intestinal samples from each section were immersed in formaldehyde. Paraffin sections of 6-mm thickness were made from each sample, stained with hematoxylin and eosin, and examined under light microscopy. Villus height and crypt depth were analyzed from each preparation. The length of the intestinal villi and the depth of the intestinal crypt were measured with linear-scaled graticule.

\section{Statistical Analysis}

All data were analyzed by the GLM procedure of SAS 9.1 (SAS Institute Inc., 2003). Dunnett's test was used to compare the means. All statements of significance were based on $p<0.05$.

\section{RESULTS}

The effects of cereal type and ENZ and SB addition on the performance of broilers are presented in Table 2. Chicks fed wheat diets consumed significantly ( $p$ $<0.01$ ) less feed than the corn-fed chicks. Both ENZ supplementation and SB addition significantly increased $\mathrm{Fl}(\mathrm{p}<0.01)$. There was no significant interaction between cereal type and ENZ supplementation and SB addition. A significant $(p<0.01)$ interaction between cereal type and ENZ supplementation was observed for WG. Weight gain was reduced $(p<0.01)$ when the wheat-based diet was fed during the entire experiment compared with the birds were fed cornbased diet. WG was significantly $(p<0.01)$ influenced by ENZ supplementation. No significant interaction ( $p>0.05$ ) was observed for feed/gain ratio on over entire experiment. Feed per gain ratio was affected by cereal type from d 10 to 21 of the experiment (1.59 vs. 1.49; for wheat and corn based diets respectively, $p<0.01)$, regardless of ENZ and SB additions. ENZ supplementation significantly ( 1.58 vs. $1.50 ; p<0.05$ ) decreased feed per gain ratio from d 10 to 21 of the experiment. Feed per gain ratio was not affected by enzyme supplementation and SB addition during the grower phase and over the entire experimental period. In general, the feed per gain ratio was significantly poorer for chicks fed wheat diet without ENZ. 
Table $\mathbf{2}$ - The effect of cereal type, enzyme and sodium butyrate addition on performance

\begin{tabular}{|c|c|c|c|c|c|c|c|c|c|c|}
\hline \multirow{2}{*}{ Item } & & \multicolumn{3}{|c|}{ Feed intake (g) } & \multicolumn{3}{|c|}{ Weight gain (g) } & \multicolumn{3}{|c|}{ Feed to gain ratio } \\
\hline & & $10-21 d$ & $22-42 d$ & $10-42 d$ & $10-21 d$ & $22-42 d$ & $10-42 d$ & $10-21 d$ & $22-42 d$ & $10-42 d$ \\
\hline \multicolumn{11}{|c|}{ Main effects } \\
\hline \multirow{2}{*}{ Cereal type } & W & $598^{a}$ & $2892^{b}$ & $3490^{b}$ & $389.6^{b}$ & $1418^{b}$ & $1807.7^{b}$ & $1.59^{a}$ & $2.04^{a}$ & $1.93^{a}$ \\
\hline & $C$ & $659.2^{\mathrm{b}}$ & $2918^{a}$ & $3578^{a}$ & $443.7^{a}$ & $1534^{a}$ & $1978^{a}$ & $1.49^{b}$ & $1.90^{\mathrm{b}}$ & $1.81^{\mathrm{b}}$ \\
\hline SEM & & 2.36 & 2.90 & 3.61 & 2.68 & 7.14 & 7.83 & 0.012 & 0.010 & 0.008 \\
\hline \multirow{2}{*}{ Enz } & A0 & $617.2^{b}$ & $2894^{b}$ & $3511.7^{b}$ & $406.4^{b}$ & $1463.5^{b}$ & $1870.2^{b}$ & $1.58^{a}$ & 1.98 & 1.88 \\
\hline & A1 & $440^{a}$ & $2916^{a}$ & $3556.5^{a}$ & $426.9^{a}$ & $1488.5^{\mathrm{a}}$ & $1915.5^{\mathrm{a}}$ & $1.50^{\mathrm{b}}$ & 1.96 & 1.86 \\
\hline SEM & & 2.36 & 2.90 & 3.61 & 2.68 & 7.14 & 7.83 & 0.012 & 0.010 & 0.008 \\
\hline \multirow{2}{*}{ SB } & BO & $616.2^{b}$ & $2896.5^{b}$ & $3513^{b}$ & 420.2 & 1466.2 & 1887 & $1.52^{b}$ & 1.98 & 1.86 \\
\hline & B1 & $641^{a}$ & $2913.5^{\mathrm{a}}$ & $3555.2^{a}$ & 413.1 & 1485.7 & 1898.7 & $1.56^{a}$ & 1.96 & 1.87 \\
\hline SEM & & 2.36 & 2.90 & 3.61 & 2.68 & 7.14 & 7.83 & 0.012 & 0.010 & 0.008 \\
\hline
\end{tabular}

\section{Interaction effects}

\begin{tabular}{|c|c|c|c|c|c|c|c|c|c|}
\hline Corn & 643 & 2949 & 3593 & 440 & 1521 & 1962 & 1.46 & 1.94 & 1.83 \\
\hline Wheat & 564 & 2831 & 3395 & 392 & 1388 & 1780 & 1.65 & 2.04 & 1.91 \\
\hline CornxEnz & 650 & 2908 & 3558 & 442.6 & 1526 & 1969 & 1.47 & 1.90 & 1.81 \\
\hline Corn $\times$ SB & 663 & 2901 & 3565 & 440.7 & 1529 & 1970 & 1.51 & 1.90 & 1.81 \\
\hline WheatxEnz & 608 & 2898 & 3506 & 406.4 & 1430 & 1837 & 1.49 & 2.03 & 1.91 \\
\hline Wheat×SB & 599 & 2895 & 3494 & 353.1 & 1416 & 1769 & 1.69 & 2.05 & 1.97 \\
\hline CornxEnzxSB & 681 & 2914 & 3596 & 451.6 & 1560 & 2011 & 1.51 & 1.86 & 1.79 \\
\hline WheatxEnzxSB & 621 & 2944 & 3566 & 406.9 & 1438 & 1845 & 1.53 & 2.05 & 1.93 \\
\hline SEM & 4.72 & 5.80 & 7.23 & 5.26 & 14.29 & 15.66 & 0.025 & 0.019 & 0.015 \\
\hline
\end{tabular}

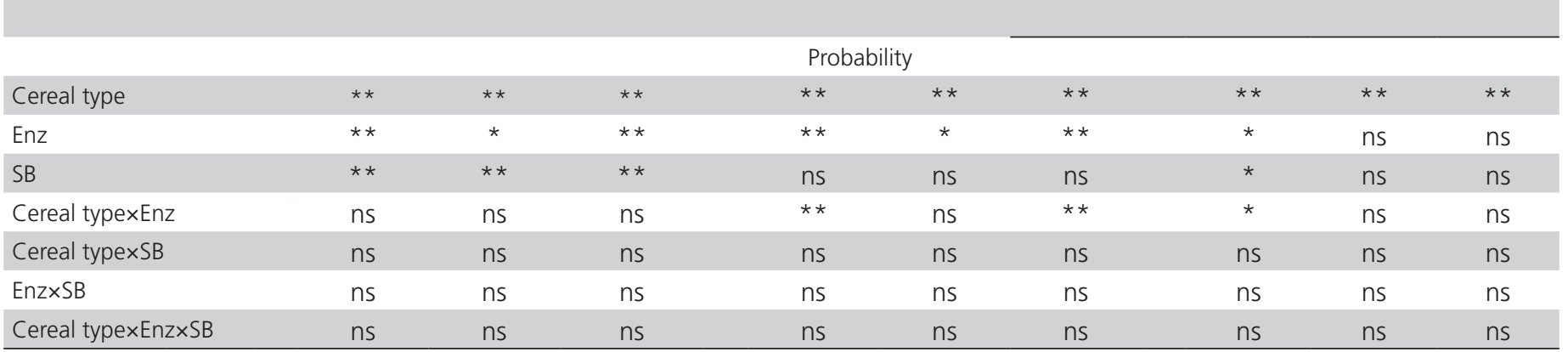

$\mathbf{W}=$ Wheat-based diet; $\mathbf{C}=$ Corn-based diet; $\mathbf{A} \mathbf{0}=$ Diet without enzyme; $\mathbf{A} \mathbf{1}=$ Diet containing enzyme; $\mathbf{B} \mathbf{0}=$ Diet without sodium butyrate; $\mathbf{B} \mathbf{1 =}$ Diet containing sodium butyrate.

$a, b, .$. Means not sharing a superscript letter in a column are significantly different at $p<0.05$.

Table 3 presents the effects of cereal type, ENZ supplementation and SB addition on the relative organ weights at $42 \mathrm{~d}$ of age broilers. Using wheat instead of corn significantly increased the relative weight of the proventriculus $(p<0.01)$, gizzard $(p<0.05)$ and liver $(p<0.05)$ at the end of experiment. In general, ENZ supplementation numerically decreased weights of different segments of the gastrointestinal tract (GIT), but SB addition had no effect ( $p>0.05$ ) on the relative weights of the proventriculus, gizzard, pancreas, liver and heart. Type of cereal influenced $(p<0.05)$ relative weights and lengths of the duodenum and caeca (Table 4); however, cereal type only affected lengths of the Jejunum and ileum in small intestine. ENZ supplementation reduced duodenum relative length on $d 42$. Also, the effect of the interaction on cecum weight between cereal type and ENZ supplementation was significant $(p<0.05)$.

The influences of cereal type, ENZ and SB on intestinal morphology are presented in Table 5. Villus height, crypt depth $(p<0.05)$ and crypt depth to villus height ratio $(p<0.01)$ in duodenum were significantly affected by cereal type. This study showed that villi were higher in the duodenum than in the jejunum and ileum in all treatment groups, which its consistent with the major role that the duodenum plays in nutrient 
absorption. Enzyme supplementation did not affect villus height, crypt depth or crypt depth to villus height ratio in the duodenum. Villus height $(p=0.09)$ and crypt depth to villus height ratio $(p=0.07)$ in the duodenum were numerically higher in the SB-fed group. Villus height $(p<0.05)$, crypt depth $(p<0.01)$ and crypt depth to villus height ratio $(p<0.01)$ in the jejunum were significantly increased by cereal type and SB addition. There were no significant effects of cereal type, ENZ supplementation and SB addition on the villus height, crypt depth and crypt depth to villus height ratio in the ileum.

\section{DISCUSSION}

The results of the current study showed that birds fed the cornbased diets had overall superior WG, $\mathrm{Fl}$ and feed/gain ratio compared with those fed the wheat-based diets. In general, wheat has lower nutritional value than corn because it contains high amounts of watersoluble and viscous NSP (Leeson \& Summers, 2005). Arabinoxylans are known to adversely affect nutrient utilization, $\mathrm{FI}$ and growth performance of broiler chickens by increasing the viscosity of intestinal contents (Choct \& Annison, 1992a,b), which can be prevented by adding NSP-degrading enzymes (Friesen et al., 1992; Choct et al., 1999; Wang et al., 2005). Previous research showed that the ENZ supplementation was effective in viscosity reduction, which resulted in higher fat, starch, nitrogen, and NSP digestibility in the small intestine of young broiler chickens fed wheat-based diets (Meng et al., 2004). The results of this study are in agreement with these findings, because when enzyme was added to the wheat-based diets, an increment in BW and $\mathrm{Fl}$ was observed over entire experiment. However, the deterioration of feed/gain ratio was significant in birds fed the wheat-based diets during the entire experimental period, despite the fact that birds at grower phase of production are known to be able to tolerate high intestinal viscosity (Friesen et al., 1992). The results of the current study demonstrated that the cell walldegrading activities are at least of equal importance as the viscosity-reducing aspects.

The present experiment showed that SB addition did not influence the WG of broilers, only their feed intake. The results of this experiment are consistent with the findings of Leeson et al. (2005), who indicated that the dietary addition of fumaric acid did not affect WG of broilers, but did improve FCR. On the other hand, Pinchasov \& Jensen (1989) reported that butyric acid, unlike other acids such as propionic acid, did not reduce feed intake. In the current study, the addition

Table 3 - Relative weight (\%) of organs (crop, proventriculus, gizzard, pancreas, liver and heart) of male broilers at 42 days of age

\begin{tabular}{|c|c|c|c|c|c|c|}
\hline Item & & Proventriculus & Gizzard & Pancreas & Liver & Heart \\
\hline \multicolumn{7}{|l|}{ Main effects } \\
\hline \multirow{2}{*}{ Cereal type } & W & $0.575 a$ & $2.46 a$ & 0.23 & $2.18 a$ & 0.55 \\
\hline & C & $0.564 b$ & $2.31 \mathrm{~b}$ & 0.22 & $1.97 b$ & 0.51 \\
\hline SEM & & 0.02 & 0.08 & 0.01 & 0.06 & 0.02 \\
\hline \multirow{2}{*}{ Enz } & AO & 0.59 & 2.45 & 0.23 & 2.11 & 0.53 \\
\hline & A1 & 0.55 & 2.30 & 0.22 & 2.04 & 0.54 \\
\hline SEM & & 0.02 & 0.08 & 0.01 & 0.06 & 0.02 \\
\hline \multirow{2}{*}{ SB } & BO & 0.59 & 2.42 & 0.22 & 2.06 & 0.51 \\
\hline & B1 & 0.54 & 2.34 & 0.22 & 2.08 & 0.55 \\
\hline SEM & & 0.02 & 0.08 & 0.01 & 0.06 & 0.02 \\
\hline
\end{tabular}

\begin{tabular}{|c|c|c|c|c|c|}
\hline \multicolumn{6}{|l|}{ Interaction effects } \\
\hline Corn & 0.59 & 2.17 & 0.208 & 1.93 & 0.55 \\
\hline Wheat & 0.70 & 2.38 & 0.222 & 2.27 & 0.49 \\
\hline CornxEnz & 0.60 & 2.38 & 0.204 & 1.95 & 0.47 \\
\hline Corn $\times$ SB & 0.61 & 2.3 & 0.209 & 2 & 0.52 \\
\hline WheatxEnz & 0.66 & 2.44 & 0.215 & 2.09 & 0.53 \\
\hline Wheat×SB & 0.68 & 2.41 & 0.228 & 2.21 & 0.54 \\
\hline Corn×Enz×SB & 0.60 & 2.38 & 0.205 & 2.05 & 0.51 \\
\hline WheatxEnzxSB & 0.68 & 2.63 & 0.215 & 2.12 & 0.63 \\
\hline SEM & 0.107 & 0.17 & 0.009 & 0.18 & 0.59 \\
\hline \multicolumn{6}{|c|}{ Probability } \\
\hline Cereal type & ** & * & * & * & ns \\
\hline Enz & ns & ns & ns & ns & ns \\
\hline SB & ns & ns & ns & ns & ns \\
\hline Cereal typexEnz & ns & ns & ns & ns & ns \\
\hline Cereal typexSB & ns & ns & ns & ns & ns \\
\hline EnzxSB & ns & ns & ns & ns & ns \\
\hline Cereal typexEnz×SB & ns & ns & ns & ns & ns \\
\hline
\end{tabular}

W $=$ Wheat-based diet $\mathrm{C}=$ Corn-based diet; $\mathrm{A} 0=$ Diet without enzyme; $\mathrm{A} 1=$ Diet containing enzyme; $\mathrm{B} 0=$ Diet without sodium butyrate; $\mathrm{B} 1=$ Diet containing sodium butyrate.

$a, b, \ldots$ Means not sharing a superscript letter in a column are significantly different at $p<0.05$. 
Table 4 - Relative weight (\%) and length $\left(\mathrm{cm} \mathrm{kgBW}^{-1}\right)$ of the intestinal tract of male broilers at 42 days of age

\begin{tabular}{|c|c|c|c|c|c|c|c|c|}
\hline \multirow[b]{2}{*}{ Item } & & \multicolumn{2}{|c|}{ Duodenum } & \multicolumn{2}{|c|}{ Jejunum } & \multicolumn{2}{|c|}{ Ileum } & Caeca \\
\hline & & $\circ^{\circ}$ & $\begin{array}{l}\hat{3} \\
\hat{\theta} \\
\sum_{j}^{\infty}\end{array}$ & $\circ^{\circ}$ & $\begin{array}{l}\hat{3} \\
\hat{\theta} \\
\sum_{\leq}^{\infty}\end{array}$ & $\circ^{\circ}$ & $\begin{array}{l}\hat{3} \\
\widehat{\hat{a}} \\
\sum_{1}^{\infty}\end{array}$ & ஃ \\
\hline \multicolumn{9}{|c|}{ Main effects } \\
\hline \multirow{2}{*}{ Cereal type } & W & $0.768^{a}$ & $1.49^{a}$ & 1.73 & $3.77^{\mathrm{a}}$ & 1.01 & $2.45^{\mathrm{a}}$ & $1.55^{\mathrm{a}}$ \\
\hline & C & $0.659^{b}$ & $1.28^{b}$ & 1.62 & $3.41^{\mathrm{b}}$ & 0.99 & $2.27^{\mathrm{b}}$ & $1.35^{b}$ \\
\hline SEM & & 0.032 & 0.036 & 0.56 & 0.027 & 0.050 & 0.056 & 0.035 \\
\hline \multirow{2}{*}{ Enz } & AO & 0.75 & $1.44^{\mathrm{a}}$ & 1.72 & 3.63 & 1.03 & 2.38 & 1.49 \\
\hline & A1 & 0.677 & $1.33^{b}$ & 1.64 & 3.56 & 0.968 & 2.34 & 1.41 \\
\hline SEM & & 0.032 & 0.036 & 0.056 & 0.027 & 0.050 & 0.056 & 0.035 \\
\hline \multirow{2}{*}{ SB } & BO & 0.725 & 1.40 & 1.68 & 3.63 & 0.997 & 2.39 & 1.45 \\
\hline & B1 & 0.702 & 1.37 & 1.68 & 3.56 & 1.00 & 2.33 & 1.44 \\
\hline SEM & & 0.032 & 0.036 & 0.56 & 0.027 & 0.050 & 0.056 & 0.035 \\
\hline
\end{tabular}

\begin{tabular}{|c|c|c|c|c|c|c|c|}
\hline \multicolumn{8}{|l|}{ Interaction effects } \\
\hline Corn & 0.68 & 1.29 & 1.63 & 3.43 & 0.98 & 2.27 & 1.33 \\
\hline Wheat & 0.85 & 1.62 & 1.79 & 3.90 & 1.09 & 2.53 & 1.63 \\
\hline CornxEnz & 0.67 & $1.30^{\mathrm{b}}$ & 1.61 & 3.42 & 0.95 & 2.34 & $1.39^{b}$ \\
\hline Corn $\times$ SB & 0.66 & 1.28 & 1.07 & 3.40 & 1.03 & 2.23 & 1.32 \\
\hline Wheat×Enz & 0.70 & $1.39^{a}$ & 1.66 & 3.73 & 0.96 & 2.41 & $1.45^{\mathrm{a}}$ \\
\hline Wheat×SB & 0.81 & 1.55 & 1.77 & 3.77 & 1.04 & 2.47 & 1.66 \\
\hline CornxEnzxSB & 0.62 & 1.25 & 1.59 & 3.38 & 0.98 & 2.21 & 1.34 \\
\hline Wheat×Enz×SB & 0.71 & 1.36 & 1.68 & 3.67 & 0.97 & 2.40 & 1.44 \\
\hline SEM & 0.09 & 0.07 & 0.15 & 0.05 & 0.14 & 011 & 0.09 \\
\hline \multicolumn{8}{|c|}{ Probability } \\
\hline Cereal type & * & ** & ns & ** & ns & * & ** \\
\hline Enz & ns & * & ns & 0.07 & ns & ns & ns \\
\hline SB & ns & ns & ns & ns & ns & ns & ns \\
\hline Cereal typexEnz & ns & ns & ns & ns & ns & ns & * \\
\hline Cereal typexSB & ns & ns & ns & ns & ns & ns & ns \\
\hline Enz×SB & ns & ns & ns & ns & ns & ns & ns \\
\hline Cereal typexEnz×SB & ns & ns & ns & ns & ns & ns & ns \\
\hline
\end{tabular}

$\mathrm{W}=$ Wheat-based diet; $\mathrm{C}=$ Corn-based diet; $\mathrm{A} 0=$ Diet without enzyme; $\mathrm{A} 1=$ Diet containing enzyme; $\mathrm{B} 0=$ Diet without sodium butyrate; $\mathrm{B} 1=\mathrm{Diet}$ containing sodium butyrate.

$\mathrm{a}, \mathrm{b}, \ldots . \cdot$ Means not sharing a superscript letter in a column are significantly different at $p<0.05$.

of $0.02 \%$ SB to the diet increased FI. In other studies, the use of buffered propionic acid (Izat et al., 1990), commercial organic acid product (Chaveerach et. al., 2004) or 5 and $10 \mathrm{~g} / \mathrm{kg}$ feed of formic acid (Hernandez et al., 2006) also had no significant effect on the growth performance of broiler chickens.

In general, the use of wheat-based diets significantly altered the morphology of the different GIT segments compared with corn-based diets at the end of experiment. By using wheat in diet, there was a linear $(p<0.01)$ increase in relative weights of proventriculus, gizzard and liver on d 42. Presumably the increased weight is accelerated by the presenced of arabinoxylans in wheat-based diets (Annison \& Choct, 1991). This NSP can increase the viscosity of the digesta and prevent effective contact between substrates and the digestive enzymes, leading to significant changes of the structure and function of intestine (Dworkin et al., 1976) and organs. The activities of the GIT secretory mechanisms may be increased to adjust to 
these changes. Thus, this may influence the weight of the GIT, proventriculus, gizzard and liver. Brenes et al. (1993) indicated that this increased size and weight of intestine and GIT could be an adaptive response to an increased need for ENZ. When supplementing enzymes in the wheat-based diets, a higher proportion of NSP may be digested, which may reduce the secretory function of the responding organs and GIT segments, and therefore, organ size may decrease.
Good intestinal health is essential to achieve the optimal growth rates and feed efficiency. Antimicrobial agents (e.g., antibiotics, SB, etc.) are known to reduce intestinal pathogen levels, which in turn decreases the presence of toxins that causes changes in the intestinal morphology, affecting particularly the villi and the crypts. In general, SB supplementation increased both villus height and crypt depth. It has been demonstrated that short-chain fatty acids stimulate the proliferation

Table 5 - Effects of cereal type, ENZ supplementation and SB addition on villus height, crypt depth and crypt depth to villus height ratio in different sections of the small intestine of birds.

\begin{tabular}{|c|c|c|c|c|c|c|c|c|c|c|}
\hline \multirow{2}{*}{ Item } & & \multicolumn{3}{|c|}{ Duodenum } & \multicolumn{3}{|c|}{ Jejunum } & \multicolumn{3}{|c|}{ Ileum } \\
\hline & & 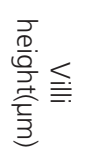 & 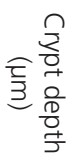 & 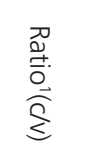 & 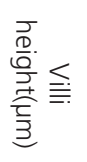 & 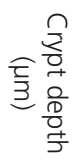 & 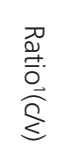 & $\frac{\frac{\bar{D}}{0} .}{\frac{0}{\bar{D}} \leqq}$ & 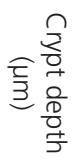 & 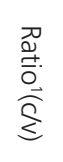 \\
\hline \multicolumn{11}{|c|}{ Main effects } \\
\hline \multirow{2}{*}{ Cereal type } & W & $1065^{b}$ & $389^{a}$ & $2.81^{b}$ & 942 & 240 & 3.93 & 683 & 194 & 3.79 \\
\hline & C & $1181^{a}$ & $315^{b}$ & $3.80^{\mathrm{a}}$ & 978 & 247 & 3.97 & 627 & 189 & 3.55 \\
\hline SEM & & 33 & 21 & 0.18 & 33 & 3 & 0.13 & 47 & 27 & 0.52 \\
\hline \multirow{2}{*}{ Enz } & $\mathrm{AO}$ & 1117 & 352 & 3.30 & 933 & 244 & 3.83 & 702 & 192 & 3.82 \\
\hline & A1 & 1129 & 351 & 3.31 & 987 & 243 & 4.07 & 608 & 192 & 3.52 \\
\hline SEM & & 33 & 21 & 0.18 & 33 & 3 & 0.13 & 47 & 27 & 0.52 \\
\hline \multirow{2}{*}{ SB } & BO & 1078 & 371 & 3.03 & 920 & 247 & $3.73^{b}$ & 644 & 188 & 3.62 \\
\hline & B1 & 1167 & 333 & 3.57 & 1000 & 240 & $4.17^{a}$ & 666 & 195 & 3.71 \\
\hline SEM & & 33 & 21 & 0.18 & 33 & 3 & 0.13 & 47 & 27 & 0.52 \\
\hline
\end{tabular}

\begin{tabular}{|c|c|c|c|c|c|c|c|c|c|}
\hline \multicolumn{10}{|l|}{ Interaction effects } \\
\hline Corn & 1130 & 320 & 3.5 & 980 & 215 & 4.6 & 610 & 182 & 3.4 \\
\hline Wheat & 1010 & 420 & 2.4 & 840 & 258 & 3.3 & 593 & 188 & 3.2 \\
\hline Cornxenz & 1140 & 330 & 3.4 & 980 & 217 & 4.5 & 609 & 189 & 3.2 \\
\hline Corn $\times$ SB & 1220 & 310 & 3.9 & 1010 & 211 & 4.8 & 618 & 178 & 3.5 \\
\hline WheatxEnz & 1040 & 420 & 2.5 & 890 & 247 & 3.6 & 595 & 195 & 3.1 \\
\hline Wheat×SB & 1100 & 360 & 3.1 & 960 & 236 & 4.1 & 606 & 183 & 3.3 \\
\hline Corn×EnzxSB & 1240 & 300 & 4.1 & 1010 & 206 & 4.9 & 609 & 181 & 3.4 \\
\hline WheatxEnz×SB & 1100 & 350 & 3.1 & 970 & 225 & 4.3 & 604 & 182 & 3.3 \\
\hline \multirow[t]{2}{*}{ SEM } & 98 & 61 & 0.54 & 46 & 8.2 & 0.27 & 27 & 21 & 0.51 \\
\hline & \multicolumn{9}{|c|}{ Probability } \\
\hline Cereal type & * & * & $\star *$ & ** & $\star *$ & ** & ns & ns & ns \\
\hline Enz & ns & ns & ns & ns & ns & ns & ns & ns & ns \\
\hline SB & 0.09 & ns & 0.07 & * & ** & ** & ns & ns & ns \\
\hline Cereal typexEnz & ns & ns & ns & ns & ns & ns & ns & ns & ns \\
\hline Cereal typexSB & ns & ns & ns & ns & 0.09 & ns & ns & ns & ns \\
\hline EnzxSB & ns & ns & ns & ns & ns & ns & ns & ns & ns \\
\hline Cereal typexEnz×SB & ns & ns & ns & ns & ns & ns & ns & ns & ns \\
\hline
\end{tabular}

$\mathrm{W}=$ Wheat-based diet; $\mathrm{C}=$ Corn-based diet; $\mathrm{A} 0=$ Diet without enzyme; $\mathrm{A} 1=$ Diet containing enzyme; $\mathrm{B} 0=$ Diet without sodium butyrate; $\mathrm{B} 1=$ Diet containing sodium butyrate.

a,b,... Means not sharing a superscript letter in a column are significantly different at $p<0.05$.

Crypt depth to villus height ratio 
of normal crypt cells, improving healthy tissue turnover and maintenance (Scheppach et al., 1995). This effect was shown by Frankel et al. (1994), who found an increase in villus height and crypt depth in the jejunum of rats fed diets supplemented with butyric acid. Also, Garcia et al. (2007) reported that formic acid supplementation increased both villus height and crypt depth. Johnson et al. (1988) reported that soluble fermentable polysaccharides with high viscosity stimulate crypt cell proliferation rate in the small intestine of rats. It can be concluded that the negative effects of NSP are related to their capability of increasing digesta viscosity, consequently leading to changes in gut morphology and in the efficiency of nutrient utilization by chickens.

\section{CONCLUSION}

In summary, enzymes (e. g., Grindazyme) may improve the performance of broilers consuming a wheat-based diet. The beneficial effect of enzyme supplementation was probably due to better nutrient utilization as a consequence of decreased intestinal viscosity and elimination of the nutrient-encapsulating effect of the cell wall polysaccharides. Furthermore, enzyme inclusion may reduce decrease the size of the digestive organs and of the GIT to some extent. The addition of SB may improve intestinal health. These results may aid the development of nutritional strategies to improve the performance of broiler chickens without the use antibiotic growth promoters.

\section{REFERENCES}

Annett CB, Viste JR, Chirino-Trejo M, Classen HL, Middleton DM, Simko E. Necrotic enteritis: effect of barley, wheat and corn diets on proliferation of Clostridium perfringens type A. Avian Diseases 2002;31:599-602.

Annison G, Choct M. Anti-nutritive activities of cereal non-starch polysaccharides in broiler diets and strategies minimizing their effects. World's Poultry Science Journal 1991;47:232-242.

Bedford MR. Exogenous enzymes inmonogastric nutrition their current value and future benefits. Animal Feed Science and Technology 2000;86:1-13.

Bedford MR, Apajalahti J. Microbial interactions in the response to exogenous enzyme utilization. Pages 299-314 In: Bedford MR Patridge $\mathrm{GG}$, editor Enzimes in farm animal nutrition. Oxon: $\mathrm{CABI}$ Publishing; 2001. p.299-314.

Branton SL, Lott BD, Deaton JW, Maslin WR, Austin FW, Pote LM, Keirs RW, Latour MA, Day EJ. The effect of added complex carbohydrates or added dietary fibre on necrotic enteritis lesions in broiler chickens. Poultry Science 1997;76:24-28.

Brenes A, Smith M, Guenter W, Marquardt RR. Effect of enzyme supplementation on the performance and digestive tract size of broiler chickens fed wheat- and barley-based diets. Poultry Science $1993 ; 72: 1731-1739$
Chaveerach P, Keuzenkamp DA, Lipman LJA, Van Knapen F. Effect of organic acids in drinking water for young broilers on Campylobacter infection, volatile fatty acid production, gut microflora and histologica cell changes. Poultry Science 2004;83:330-334

Choct M, Annison G. The inhibition of nutrient digestion by wheat pentosans. British Journal of Nutrition 1992a; 67:123-132.

Choct M, Annison G. Antinutritive effect of wheat pentosans in broiler chickens: Role of viscosity and gut microflora. British Poultry Science 1992b;33:821-834

Choct M, Hughes RJ, Bedford MR. Effects of a xylanase on individual bird variation, starch digestion throughout the intestine, and ileal and cecal volatile fatty acid production in chickens fed wheat. British Poultry Science 1999; 40:419-422.

Choct M, Hughes RJ, Wang J, Bedford MR, Morgan AJ, Annison G. Increased small intestinal fermentation is partly responsible for the anti-nutritive activity of non-starch polysaccharides in chickens. British Poultry Science 1996; 37:609-621

Dibner JJ, Buttin P. Use of organic acid as a model to study the impact of gut microflora on nutrition and metabolism. Journal of Applied Poultry Research 2002:11:453-463.

Dierick NA, Decuypere JA, Molly K, vanBeek E, Vanderbeke E. The combined use of triacylglycerols containing medium-chain fatty acids and exogenous lipolytic enzymes as an alternative for nutritional antibiotics in piglet nutrition. Livestock Production Science 2002;75:129-142.

Dworkin LD, Levine GM, Farber JJ, Spector NH. Small intestinal mass of the rat is partially determined by indirect effects on intraluminal nutrition. Gastroenterology 1976;71:626-630.

Frankel WL, Zhang W, Singh A, Klurfeld DM, Don S, Sakata T, Rombeau JL. Mediation of the trophic effects of short chain fatty acids on the rat jejunum and colon. Gastroenterology 1994;106:385-390.

Friesen OD, Guenter W, Marquardt RR, Rotter BA. The effect of enzyme supplementation on the apparent metabolizable energy and nutrient digestibilities of wheat, barley, oats, and rye for the young broiler chick. Poultry Science 1992;71:1710-1721.

García V, Catalá-Gregori P, Hernández F, Megías MD, Madrid J. Effect of formic acid and plant extracts on growth, nutrient digestibility, intestine mucosa morphology, and meat yield of broilers. Journal of Applied Poultry Research 2007;16:555-562.

Garrido MN, Skjervheim M, Oppegaard H, Sorum H. Acidified litter benefits the intestinal flora balance of broiler chickens. Applied Environmental Microbiology 2004;70:5208-5213.

Hernández F, García V, Madrid J, Orengo J, Catalá P, Megías MD. Effect of formic acid on performance, digestibility, intestinal histomorphology and plasma metabolite levels of broiler chickens. British Poultry Science 2006:47:50-56

Iji PA, Hughes RS, Choct M, Tivey DR. Intestinal structure are function of broiler chickens on wheat based diets supplemented with a microbial enzyme. Asian-Australian Journal of Animal Science 2001;14:54-60.

Izat AL, Tidwell NM, Thomas RA, Reiber MA, Adams MH, Colberg M, Waldroup PW. Effects of a buffered propionic acid in diets on the performance of broiler chickens and on microflora of the intestine and carcass. Poultry Science 1990;69:818-826.

Johnson IT, Gee JM, Brown JC. plasma entroglucagon and small bowel cynokinetics in rats fed soluble nonstarch polysaccharides. American Journal of Clinical Nutrition 1988:47:1004-1009.

Kirchgessner M, Roth FX. Fumaric acid as a feed additive in pig nutrition Pig News and Information 1982;3:259-264. 
Leeson S, Namkung $\mathrm{H}$, Antongiovanni M, Lee EH. Effect of butyric acid on the performance and carcass yield on broiler chickens. Poultry Science 2005;84:1418-1422.

Leeson S, Summers JD. Commercial poultry nutrition. 3rd ed. Guelph: University Books, 2005.

Meng X, Slominski BA, Guenter W. The effect of fat type, carbohydrase, and lipase addition on growth performance and nutrient utilization of young broilers fed wheat-based diets. Poultry Science 2004;83:17181727

Monsan PF, Paul F. Oligosaccharide feed additive. In: Wallace RJ, Chesson A, editor. Biotechnology in animal feeds and feeding. R. J. Weinheim: VCH Verlagsgesellschaft; 1995. p.233-245.

National Research Council. Nutrient requirements of poultry. $9^{\text {th }}$ rev. ed. Washington: National Academy Press; 1994.

Pinchasov $Y$, Jensen LS. Effect of short cahin fatty acids on voluntary feed intake of broiler chicks. Poultry Science 1989;68:1612-1618.

Pryde SE, Duncan SH, Hold GL, Stewart CS, Flint HJ. The microbiology of butyrate formation in the human colon. FEMS Microbiology Letters 2002:217:133-139.

Ravindran V, Kornegay ET. Acidification of weaner pig diets: A review. Journal of the Science of Food and Agriculture 1993;62:313-322.

SAS Institute. SAS user's guide. Version 8 ed. Cary; 2001.

Scheppach W, Bartram HP, Richter F. Role of short-chain fatty acids in the prevention of colorectal cancer. European Journal of Cancer 1995;31A:1077-1080

Skinner JT, Izat AL, Waldroup PW. Research note: Fumaric acid enhances performance of broiler chickens. Poultry Science 1991;70:1444-1447.

Wang ZR, Qiao SY, Lu WQ, Li DF. Effects of enzyme supplementation on performance, nutrient digestibility, gastrointestinal morphology and volatile fatty acid profiles in the hindgut of broilers fed wheat-based diets. Poultry Science 2005;84:875-881.

Youn BS, Nam KT, Chang KM, Hwang SG, Choe IS. Effects of wood vinegar addition for meat quality improvement of old layer. Korean Journal of Poultry Science 2005;32:101-106. 